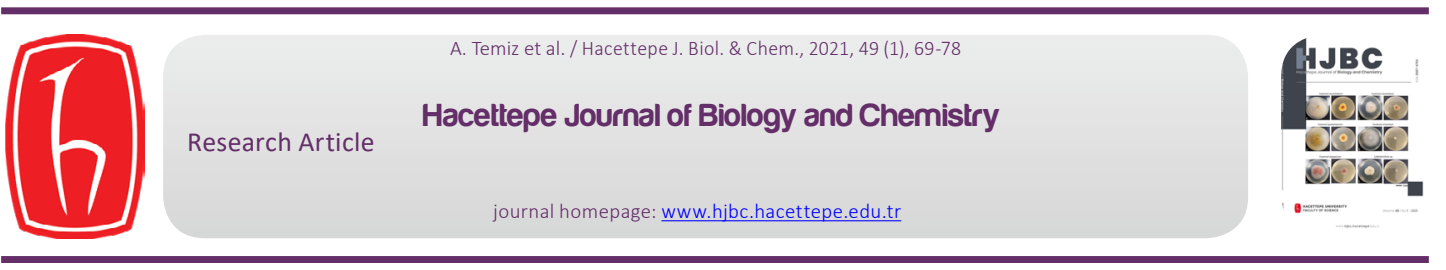

\title{
The role of the Cellular Antioxidant Defense System on Oxidative Stress in Acute Appendicitis
}

\section{Akut Apandisitlerde Hücresel Antioksidan Savunma Sisteminin Oksidatif Stres Üzerindeki Rolü}

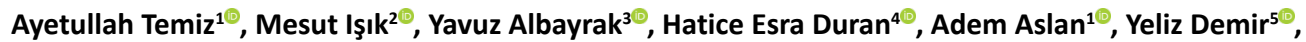 \\ Ayşe Albayrak $^{6 \bullet}$, Yılmaz Özdemir ${ }^{1 \oplus}$, Şükrü Beydemir ${ }^{7 \bullet}$ \\ ${ }^{1}$ Department of General Surgery, Education and Research Hospital, Erzurum, Turkey. \\ ${ }^{2}$ Department of Pharmacy Services, Health Services Vocational School, Harran University, Şanlıurfa, Turkey. \\ ${ }^{3}$ Department of General Surgery, Health Sciences University, Erzurum, Turkey. \\ ${ }^{4}$ Department of Medical Biochemistry, Faculty of Medicine, Kafkas University, Erzurum, Turkey. \\ ${ }^{5}$ Department of Pharmacy Services, Nihat Delibalta Göle Vocational High School, Ardahan University, Ardahan, Turkey. \\ ${ }^{6}$ Department of Infectious Diseases and Clinical Microbiology, Faculty of Medicine, Ataturk University, Erzurum, Turkey. \\ 'Department of Biochemistry, Faculty of Pharmacy, Anadolu University, Eskişehir, Turkey.
}

\section{A B STR ACT}

\begin{abstract}
$\mathrm{t}$ is known that free radicals, their products and reactive oxygen species (ROS) are associated with many diseases. The study focuses on both some changes in oxidative stress factors in patients with acute appendicitis (AA) and the changes of glutathione S-transferase (GST) and paraoxonase-I (PON1) enzyme activities in the metabolism. This study involved control group $(n=31)$ and the study group $(n=52)$. In the groups, some changes in oxidative stress factors and GST and PON1 enzyme activities which play an important role in metabolism were determined. There are changes in GST activity between study and control groups. The activity of the enzyme were significantly higher in AA groups $(p<0.01)$ than control. Malondialdehyde (MDA) levels in acute perforated appendicitis (PeA) groups were found significantly higher than control ( $p$ $<0.01)$. There is a negative correlation between mean platelet volume (MPV) and lipid peroxidation in AA patients $(r=-0.654$ $\mathrm{p}<0.01$ ). An increase in GSH production and GST activity provides an important defense mechanism against the oxidation of some macromolecules and may prevent oxidative stress in patients with appendicitis to some extent.
\end{abstract}

\section{Key Words}

Oxidative stress, acute appendicitis, cellular defense system, antioxidant enzyme.

\section{öz}

Serbest radikallerin, ürünlerinin ve reaktif oksijen türlerinin (ROS) birçok hastalıkla ilişkili olduğu bilinmektedir. Çalışma $\checkmark$ hem akut apandisitli (AA) hastalarda oksidatif stres faktörlerindeki hem de metabolizmada GST ve PON1 enzim aktivitelerindeki değişikliklere odaklanmaktadır. Bu çalışmaya kontrol grubu $(n=31)$ ve çalışma grubu $(n=52)$ dahil edildi. Gruplarda, metabolizmada önemli rol oynayan oksidatif stres faktörleri ve Glutatyon S-transferaz (GST) and paraoksanaz-I (PON1) enzim aktivitelerinde bazı değişiklikler belirlendi. Çalışma ve kontrol grupları arasında GST aktivitesinde önemli değişiklikler belirlenmiştir. Bu enzim aktivitesi AA gruplarında $(p<0.01)$ kontrolden anlamlı derecede yüksek bulunmuştur. Akut perfore apandisit (PeA) gruplarındaki malondialdehit (MDA) düzeyleri kontrolden anlamlı derecede yüksek bulunmuştur $(p<0.01)$. AA hastalarında ortalama trombosit hacmi (MPV) ile lipit peroksidasyonu arasında negatif bir korelasyon vardır $(r$ $=-0.654, p<0.01)$. GSH üretimi ve GST aktivitesindeki artış, bazı makromoleküllerin oksidasyonuna karşı önemli bir savunma mekanizması sağlar ve apandisitli hastalarda bir dereceye kadar oksidatif stresi önleyebilir.

\section{Anahtar Kelimeler}

Akut apandisit, hücresel savunma sistemi, antioksidan enzim, oksidatif stres.

Article History: Received: Apr 28, 2020; Revised: Oct 27, 2020; Accepted: Oct 27, 2020; Available Online: Dec 10, 2020. DOI: https://doi.org/10.15671/hjbc.728686

Correspondence to: S. Beydemir, Department of Biochemistry, Faculty of Pharmacy, Anadolu University, Eskişehir, Turkey; M.Işık, Department of Pharmacy Services, Health Services Vocational School, Harran University, Şanlıurfa, Turkey. 


\section{INTRODUCTION}

A cute appendicitis (AA), the most common cause of abdominal pain, is a disease requiring emergency surgery [1]. AA diagnosis is usually based on a combination of clinical information including symptoms such as right lower quadrant abdominal pain, nausea and/ or vomiting, high fever $\left(38^{\circ} \mathrm{C}\right)$, abdominal rigidity and painful urination. Moreover, it is important physical examination findings, traditional biomarkers such as absolute neutrophil count, mean platelet volume (MPV), white blood cell count (WBC), radiographic imaging (e.g. computed tomography scans and ultrasound) and C-reactive protein for AA diagnosis [2,3]. Unfortunately, clinical symptoms, laboratory and radiological outcomes are not sufficiently specific to differential diagnosis AA from other intraabdominal pathologies such as urological and gynecologic pathologies [4]. In many cases, the appendix is surgically removed unnecessarily because the diagnosis is not correct. Unnecessary removal of the appendix due to the lack of reliable laboratory data caused additional burden on the health systems, increased patient pain and reduced quality of patients life [5]. Therefore, there is a need new, easy to implement and inexpensive diagnostic tools such as some biomarkers that are high diagnostic value for AA.

Macrophages neutrophils and tissue cells secrete various reactive oxygen species (ROS) that act on macromolecules such as DNA, proteins, and lipids [6]. Increased ROS production and/or impaired antioxidant defense systems can lead to oxidative stress $[7,8]$. This may be a signal of some diseases such as cancer, atherosclerosis, Parkinson's disease and Alzheimer's disease (Schema 1).

The adverse effects of ROS are known to be regulated by the effects of antioxidant enzymes such as glutathione S-transferase (GST) and paraoxonase (PON1), which support the direct suppression of free radicals to maintain oxidative cellular balance $[9,10]$. The activity of GST having 22 family members is related with the presence of GSH. The enzyme has a crucial role for detoxification of products of oxidative stress, by conjugation with GSH, and reactive electrophilic compounds including environmental toxins [11]. The $\mathrm{Ca}^{2+}$-dependent enzyme (PON1) is high-density lipoprotein (HDL)-associated serum esterase. PON1 including 354 amino acids has mainly activities as arylesterase, paraoxonase and diazoxon activities. PON1 having detoxifying and anti-atherogenic effects protects both HDL and LDL from oxidation in oxidative stress conditions [12]. In addition, plasma total thiol (TSH) measurement is a good reflection of over-free radical formation in humans in both physiologically and pathologically $[6,13]$ Lipid damage involves the presence of lipid peroxidation products such as lipid peroxides or malondialdehyde (MDA) $[6,10,14]$. A small number of studies have investigated the relationship between AA and antioxidant enzymes. Lipid peroxidation, the glutathione system and total thiol levels have not been simultaneously investigated in previous studies. Whether there is a difference between perforated and suppurative appendicitis in terms of oxidative stresses no been clarified. In addition, if there is no difference, the determining factors have not been explained.

Consequently, in this study, we aimed to investigate the body's response to oxidative stressors in AA and the relationship between this response and the type of acute suppurative appendicitis or acute perforation appendicitis. Therefore, it was focused on both some changes in oxidative stress factors in patients with $A A$ and the changes of GST and PON1 enzyme activities in the metabolism.

\section{MATERIALS and METHODS}

The study that conducted according to provisions of the Helsinki Declaration was approved by Erzurum Regional Training and Research Hospital Clinical Research Ethics Committee (Decision number 2015/10-93). This study was carried out in the general surgery clinic of Erzurum region education and research hospital between 1 July and $31 \mathrm{Au}-$ gust 2015 with 52 patients who were diagnosed as acute appendicitis (AA) and 31 non - patient control groups. The patients were divided into three groups There was no significant difference between control groups with regard to gender or age and the patient $(p>0.05)$.

Group 1: There were 27 patients who underwent and pathologic examination diagnosed as acute suppurative appendicitis in this group.

Group 2: There were 25 patients with diagnosed perforated appendicitis as clinically and pathologically in this group

Group 3: consisted of 31 control groups. The healthy control group was selected from healthy persons who came to the hospital without any complaints, just for purposes of a check-up in the Infection Diseases Clinics, and who did not conform to the exclusion criteria. 

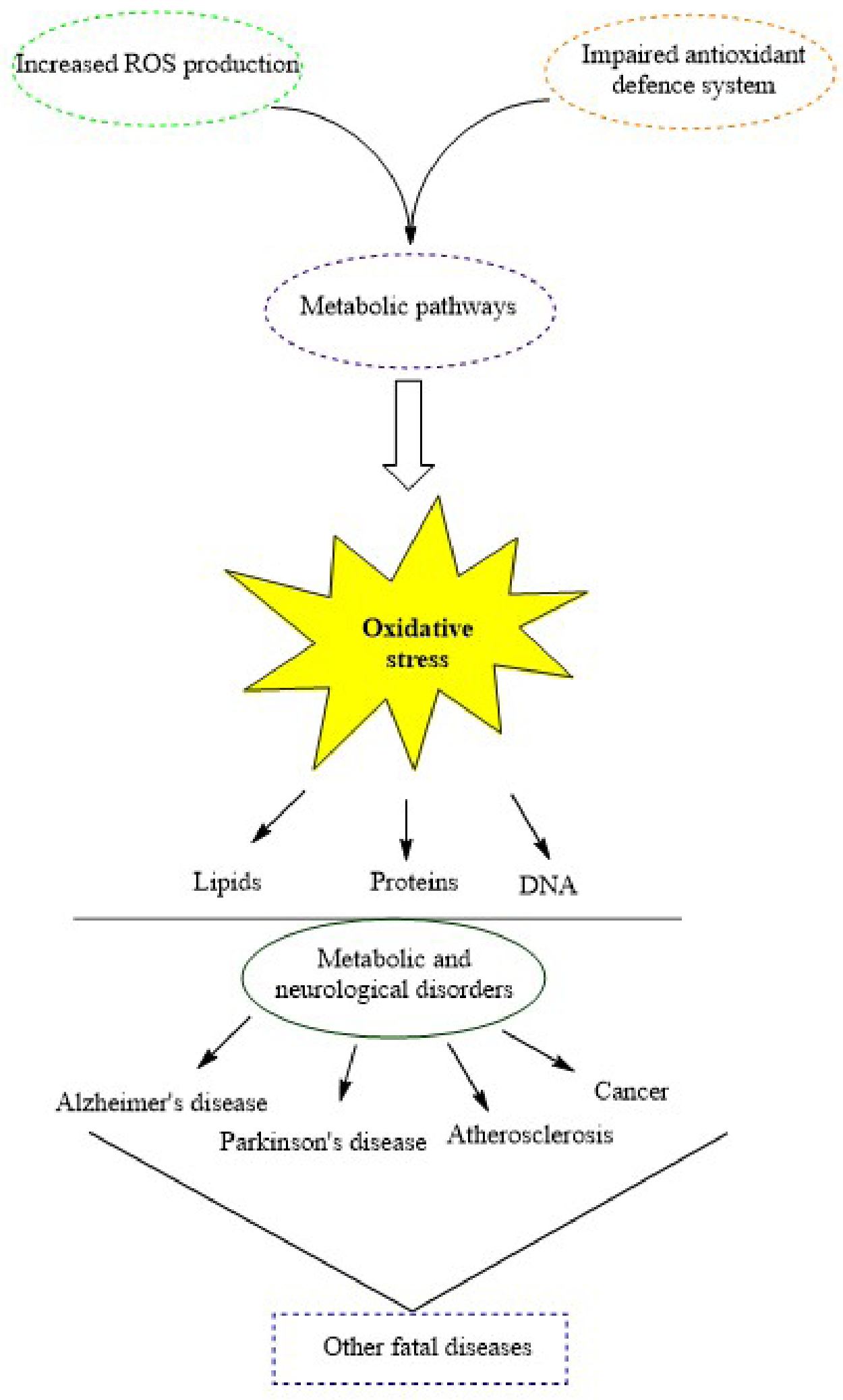

Scheme 1. ROS production and damaged antioxidant system affect the metabolic pathways and may cause oxidative stress. Thus it may lead many vital disorders such as Alzheimer's disease, Parkinson's disease, atherosclerosis and cancer. 
Inclusion and exclusion criteria all of the patients underwent operations for appendicitis on the basis of the history, relevant clinical data and physical findings. Postoperatively, the removed appendix was sent for histopathological examination. Cases where the histopathology was not consistent with appendicitis were excluded from the study. The exclusion criteria for entry into the study were prior antibiotic therapy, hematological disorders, hepatic diseases, an age $<20$ years, age $>40$ years, acute or chronic infection, cancer, peripheral vascular disease, heart failure, non-smokers, pregnancy, and other known inflammatory conditions. None of the patients had received prior anticoagulant medications, nonsteroidal anti-inflammatory drugs or oral contraceptives

\section{Data Collection}

Full blood counts were performed for participants with a history of: periumbilical or right lower quadrant pain; nausea, vomiting or anorexia; fever; abdominal examination findings and/or based on the general clinical intuition of the physician. All participants in the study group underwent appendicitis operations on the basis of their history, physical findings and relevant clinical data. Postoperatively, the removed appendix was sent for histopathological examination. Cases whose histopathology showed no appendicitis were excluded from the analyses.

\section{Sample Collection and Biomarker Assays}

Blood samples were obtained from patients on admission to hospital. Mean platelet volume (MPV) were assessed with a haemogram device (Abbott Cell-Dyn Ruby, USA). Blood samples were centrifuged in yellow-capped, gelled biochemistry tubes and kept at $-80^{\circ} \mathrm{C}$ until antioxidant enzyme levels were measured.

\section{Measurement of GSH amount}

Glutathione (GSH) was measured using the modified method of Reddy et al [15]. 5\% trichloroacetic acid treated with $20 \mu$ of serum samples were mixed with 330 $\mu \mathrm{l}$ of $1 \mathrm{mM} 5,5$-dithiobis-2-nitrobenzoate and $660 \mu \mathrm{l}$ of $67 \mathrm{mM}$ phosphate buffer ( $\mathrm{pH}$ 8.0). The samples were incubated in the dark at room temperature for $45 \mathrm{~min}$, then the absorbance was read at $412 \mathrm{~nm}$. The GSH concentration was determined as previously described [16]. GSH content was calculated as nmol GSH $\mathrm{mg} / \mathrm{ml}$ using a molar extinction coefficient of $13.6 \times 10^{3} \mathrm{M}^{-1} \mathrm{~cm}^{-1}$.

\section{Measurement of GST activity}

GST activity was measured with the modified method of Harvey and Beutler. $1 \mathrm{ml}$ of reaction mixture containing $850 \mu \mathrm{l}$ of $0.1 \mathrm{M}$ phosphate buffer, $\mathrm{pH} 6.5,20 \mu \mathrm{l}$ $20 \mathrm{mM}$ 1-chloro-2, 4-dinitrobenzene (CDNB) and $50 \mu \mathrm{l}$ $20 \mathrm{mM} \mathrm{GSH}$ was pre-incubated at $20^{\circ} \mathrm{C}$ for $10 \mathrm{~min}$. The reaction was started by adding $30 \mu \mathrm{l}$ serum and GST activity was assayed kinetically. The reaction was followed at 1 min intervals for 5 min by measuring the absorbance at $340 \mathrm{~nm}$. GST activity was determined using a molar extinction coefficient of $9.6 \mathrm{mM} / \mathrm{cm}$. Enzymatic activity was expressed as units of activity (U) per mg of protein. Each unit of activity corresponded to $1 \mathrm{nmol}$ of substrate hydrolysis per minute [17].

\section{Measurement of Malondialdehyde Level}

Malondialdehyde (MDA) level in plasma was measured using the modified method of Gubandru et al. [18]. This was determined based on the reaction with thiobarbituric acid at $70^{\circ} \mathrm{C}$ for $30 \mathrm{~min}$. The sample was mixed with two volumes of cold $5 \%(\mathrm{w} / \mathrm{v})$ trichloroacetic acid to precipitate protein. After centrifugation of the precipitate, an aliquot of the supernatant was reacted with an equal volume of $0.8 \%(\mathrm{w} / \mathrm{v})$ thiobarbituric acid, and the absorbance was read at $532 \mathrm{~nm}$.

\section{Measurement of PON1 activity}

PON1 activity was determined at $25^{\circ} \mathrm{C}$ with paraoxon (diethyl p-nitrophenyl phosphate; $1 \mathrm{mM}$ ) in $50 \mathrm{mM}$ glycine/ $\mathrm{NaOH}(\mathrm{pH} 10.5)$ containing $1 \mathrm{mM} \mathrm{CaCl}_{2}$. The PON1 enzyme assay was based on the estimation of p-nitrophenol at $412 \mathrm{~nm}$. The molar extinction coefficient of p-nitrophenol ( $\varepsilon=18.290 \mathrm{M}^{-1} \mathrm{~cm}^{-1}$ at $\left.\mathrm{pH} 10.5\right)$ was used to calculate PON1 activity [19]. One enzyme unit was defined as the amount of enzyme that catalyzed the hydrolysis of $1 \mathrm{mmol}$ of substrate at $25^{\circ} \mathrm{C}$. The assays were performed using a spectrophotometer.

\section{Measurement of total thiol amount}

TSH levels of serum samples were measured with the Ellman method [20]. The concentration of the sulfhydryl groups was calculated using reduced glutathione as the free sulfhydryl group standard, and the results were expressed as $\mu \mathrm{mol} / \mathrm{L}$. TSH was measured by a colorimetric method, by which thiol groups gave a chromogen compound with dithiobisnitrobenzoic acid in alkaline $\mathrm{pH}$. TSH concentrations were calculated using the molar absorptivity of the reaction product, thionitrobenzoic acid. 


\section{Statistical analysis}

Statistical analyses were performed with SPSS Version 20.0 (IBM SPSS Statistics for Windows, Version 20.0. Armonk, NY: IBM Corp.). Data are expressed as mean \pm standard deviation. Statistical comparisons among different groups were performed with one-way analysis of variance. Least significant difference post hoc pairwise comparison tests were also performed at the equal variances assumed. Statistical significance was defined as ${ }^{*} p<0.05, * * p<0.01$ and $* * * p<0.001$.

\section{RESULTS}

The activities of antioxidant enzymes (GST and PON1) in plasma are shown in Table 1. GST was significantly different between study and control groups. It was determined a significantly increase of GST activity in patients with acute perforated appendicitis (PeA) (102.0 \pm 9.2 EU/L) according to the control group's GST activity $(91.4 \pm 8.1 \mathrm{EU} / \mathrm{L} ; \mathrm{p}<0.001)$. Similarly, the activity of GST was also significantly increased in patients with acute phlegmonous appendicitis (PhA) (100.1 \pm 8.7 EU/L) compared to the control group (Figure 1a). On the other hand, PON1 activity was low both in patients with PhA and PeA compared to the control group. But this result had not any important, statistically (Figure 1b).
TSH levels were determined higher both in patients with $\mathrm{PhA}$ and PeA according to the control group. But significant differences were not observed ( $p>0.05$ ) (Table 1). While the GSH level in plasma was lower in PhA, it was higher in patients with PeA than the control group. But it was not observed significant differences in their results (Table 1$)(p>0.05)$. MDA levels were increased in patients with PeA compared with controls (0.7718 vs. $0.5734 \mu \mathrm{mol} / \mathrm{L}, \mathrm{p}<0.05)$. However, MDA levels in patients with PhA did not differ from those with PeA and controls $(p>0.05)$ (Table 1$)$.

There was no significant difference between the patient and control groups with regard to gender or age ( $p>$ 0.05). The ages in both groups were similar. MPV was significantly decreased in patients with PeA, with values of $6,8 \pm 1,2 \mathrm{fl}$ compared with that seen in the control group $(8,3 \pm 2,1 \mathrm{fl} ; \mathrm{p}<0.01)$. Similarly, MPV was significantly decreased in patients with $\mathrm{PhA}$, with values of $7,1 \pm 1,3 \mathrm{fl}$ compared with that seen in the control group $(8,3 \pm 2,1 \mathrm{fl}$; $\mathrm{p}<0.05$ ) (Table 1).

There is a strong negative correlation between MPV and MDA $(r=-0.654, p<0.01)$. Lipid peroxidation may increase with the decrease of MPV in patients with AA. (Figure 2).

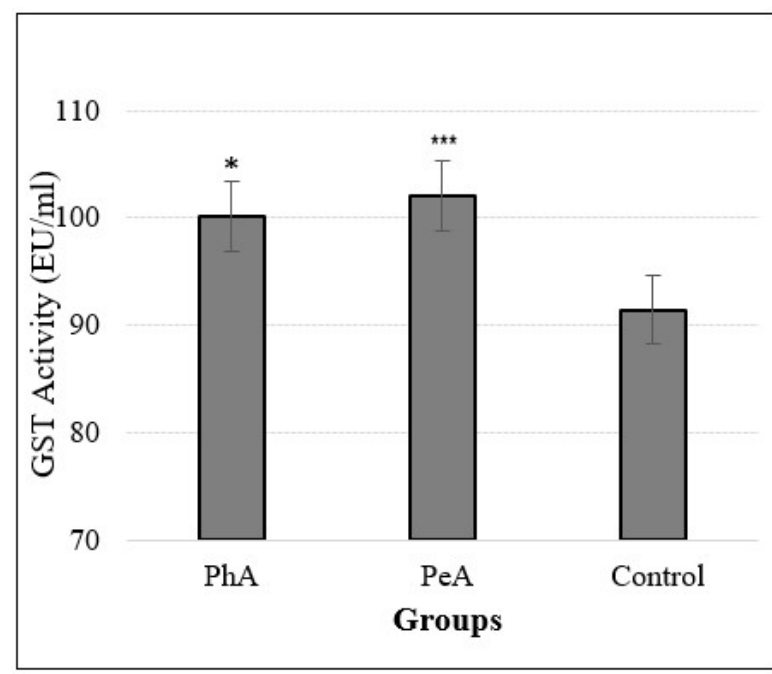

a

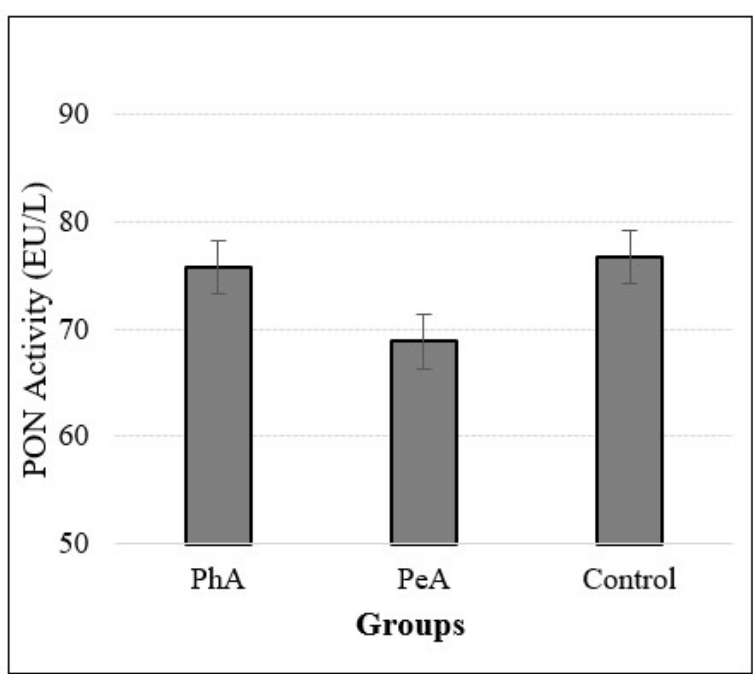

b

Figure 1. Activities of GST (b) and PON1 (b) in peripheral blood of control subjects, patients with phlegmonous or acute perforated appendicitis (PhA: Acute phlegmonous appendicitis, PeA: Acute perforated appendicitis, GST: Glutathione S-transferase, and PON: paraoxonase 1). 
Table 1. Summarize of the total result: MPV, TSH, GSH and MDA levels, GST and PON1 activities for patients and control groups.

\begin{tabular}{|c|c|c|c|c|c|c|}
\hline \multirow[b]{2}{*}{ Parameters } & \multicolumn{3}{|c|}{ Groups } & \multicolumn{3}{|c|}{$p$} \\
\hline & $\begin{array}{c}\text { PhA (Group I), } \\
\mathrm{n}: 27\end{array}$ & $\begin{array}{c}\text { PeA (Group II) } \\
n: 25\end{array}$ & $\begin{array}{c}\text { Control } \\
\text { (Group III) n: } 31\end{array}$ & $\begin{array}{l}\text { Group I } \\
\text { Group II }\end{array}$ & $\begin{array}{l}\text { Group I } \\
\text { Group III }\end{array}$ & $\begin{array}{l}\text { Group II } \\
\text { Group III }\end{array}$ \\
\hline $\mathrm{GST},(\mathrm{EU} / \mathrm{mL})$ & $100.1 \pm 8.70$ & $102.0 \pm 9.20$ & $91.4 \pm 8.10$ & $>0.05$ & $<0.005$ & $<0.001$ \\
\hline MDA, $(\mu \mathrm{mol} / \mathrm{L})$ & $0.61 \pm 0.070$ & $0.77 \pm 0.090$ & $0.57 \pm 0.06$ & $>0.05$ & $>0.05$ & $<0.05$ \\
\hline PON1, (EU/L) & $75.71 \pm 8.190$ & $68.81 \pm 7.060$ & $76.68 \pm 7.90$ & $>0.05$ & $>0.05$ & $>0.05$ \\
\hline $\mathrm{TSH},(\mu \mathrm{mol} / \mathrm{L})$ & $167.8 \pm 28.20$ & $158.1 \pm 23.70$ & $153.9 \pm 21.6$ & $>0.05$ & $>0.05$ & $>0.05$ \\
\hline$M P V,(f L)$ & $7.10 \pm 1.300$ & $6.80 \pm 1.200$ & $8.30 \pm 2.100$ & $>0.05$ & $<0.05$ & $<0.01$ \\
\hline
\end{tabular}

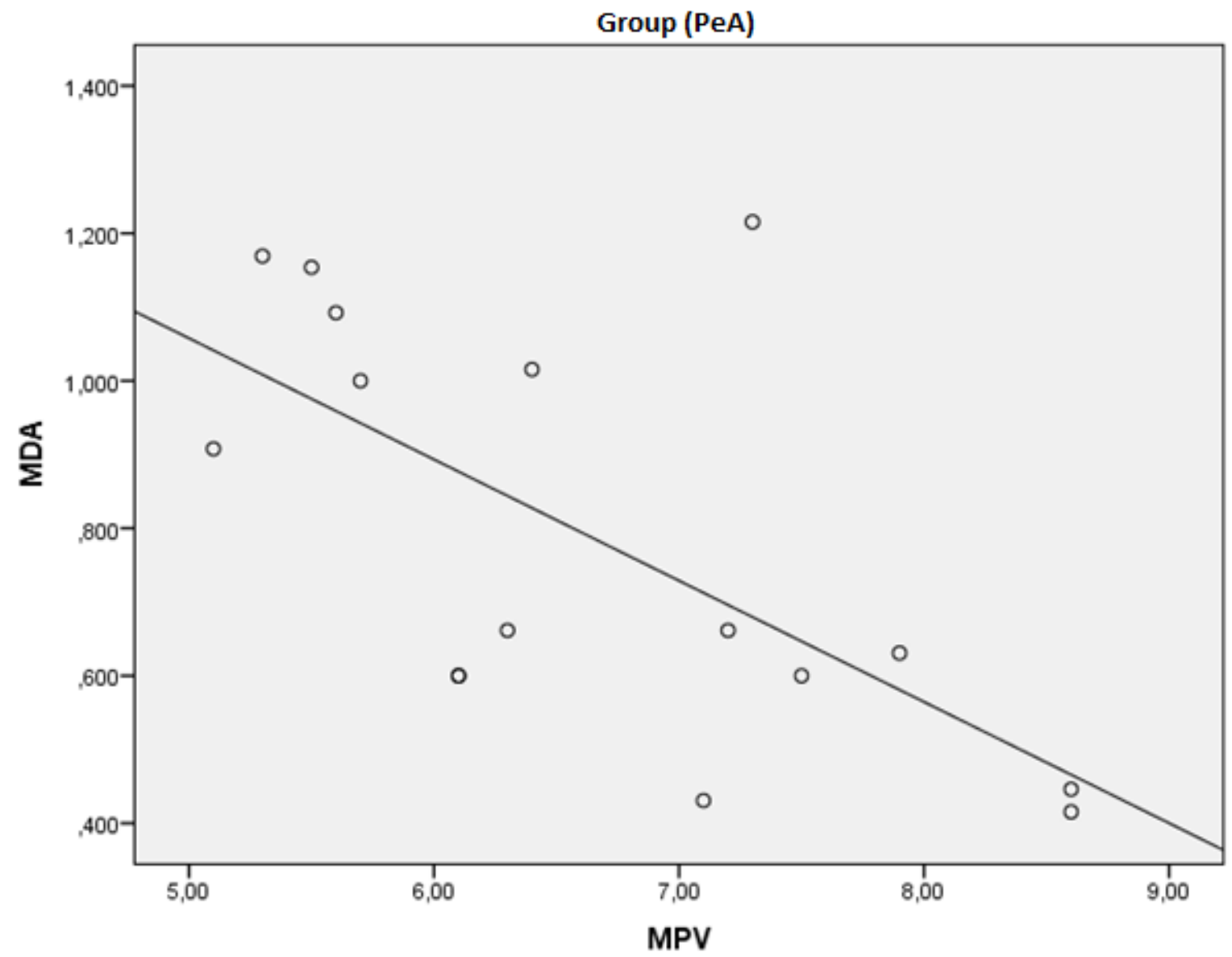

Figure 2. The correlations between MDA and MPV in patients with acute perforated appendicitis $(r=-0.654, p<0.006)$. (PeA: Acute perforated appendicitis, MPV: Mean platelet volume). 


\section{DISCUSSION}

Acute appendicitis (AA) is a common emergency presentation to general surgical services and requires emergency surgical intervention [4]. In the pathogenesis of $A A$, bacterial invasion of the appendix wall occurs, and the inflammatory reaction causes a purulent infection. This case can also cause many metabolic disorders including changing of the various enzyme activities. It is very clear that all tissues in the human body contain a lot of antioxidant enzymes to protect from harmful effects of oxidative processes. Indeed, many diseases as AA have close relationship with oxidative stress. ROS is known to involve in the pathology of many diseases, including many gastrointestinal disorders [8,21]. However, assessing of the oxidative stress is difficult with the reaction of the human body. Therefore, measuring of the oxidative stress can be no single biomarker for many disease, objectively $[22,23]$. However, determining of the oxidative parameters is important for diagnosis. Particularly, to determine the activities of various antioxidant enzymes is vital to understand the mechanism of disease and improve a treatment method.

ROS occurring by the partial reduction of molecular oxygen contain unpaired electrons. They are shortlived and aggressive molecules. For instance, superoxide $\left(\mathrm{O}_{2}{ }^{--}\right)$and hydroxyl $(\mathrm{OH} \bullet)$ are important derivatives comprised of highly unstable oxygen free radicals [24]. It is known that the effects of antioxidant enzymes such as glutathione S-transferase (GST) and paraoxonase (PON1) are crucial on ROS regulation $[9,10]$.

The low expression of antioxidant enzymes, including GST in cell and upregulated oxidative defense mechanisms plays an important role in the host defense mechanism in inflammation. Moreover, it is reported that the activity of GST has been often used as a biomarker in order to detect oxidative stress for many organisms [25-27]. Particularly, GST contributes to the detoxification of endogenously produced free radicals associated with glutathione peroxidase activity $[28,29]$ Sohail et al. (2007) investigated whether serum and plasma glutathione-S-transferase activity in vivax patients was really important. Thus, it was to be one of the important antioxidant markers for diagnostic potential and candidate for chemoprevention. They found that GST activity in serum and plasma of patients with vivax malaria were less than healthy subjects. It was an important result of the biomarker role of the GST enzyme in vivax ma- laria [28]. In our study, the serum GST activity of patients with AA were higher than the control group. This result is very important in terms of GSH production in metabolism. On the other hand, there was not any crucial difference in terms of GST activity between acute phlegmonous appendicitis (PhA) and acute perforated appendicitis, statistically (Table 1). Thus, it is thought the increased GST activity contributes to the detoxification of endogenously produced free radicals due to AA. PON1 having many enzymatic activities such as paraoxonase, arylesterase, dyazoxonase is a high-density lipoprotein-associated and including two $\mathrm{Ca}^{2+}$ ions in its structure $[30,31]$ It is a very important antioxidant enzyme in the serum. PON1 activity may decrease during infection and inflammation. Decreased PON1 activity has been observed in various diseases such as coronary artery disease, hypercholesterolemia, acute pancreatitis and lung cancer [31,32]. In our study, Although PON1 activity was found as low in patients with PhA and PeA compared to the control group, this result did no important, statistically (Figure 1b). In a study, researchers was investigated the correlation between the serum and tissue levels of oxidation parameters and the extent of inflammation in AA. They found that PON1 activity was low in patients with PhA and PeA compared to the control group [33]. However, this level of the enzyme activity was not important as in our results. In another study, researchers aimed to determine some oxidative stress parameters and paraoxonase activity in patients with a diagnosis of AA [34]. They also found similar results in our present study. PON1 had low activity levels in patients with AA compared to the control group, but it was not important, statistically. However, stable PON1 activity is vital for the structure of HDL and LDL molecules. If PON1 activity was decreased, it could be cause atherosclerotic lesions due to the LDL oxidation.

The measurement of plasma total thiol (TSH) is a good reflection of excess free radical formation in humans both physiologically and pathologically $[6,13,20]$. In a study, researchers investigated lipid peroxidation, total thiol levels and nitric oxide in AA. They studied on thirty-four patients who underwent operation with a perioperative diagnosis of $\mathrm{AA}$ and 16 age and sexmatched controls. Besides some important oxidative stress parameters, total thiol levels were also determined in the study. They determined a significant reduction in levels of TSH in AA [6]. In another study, Esen et al (2015) investigated on serum PON1 activity, total thiols levels, and oxidative status in patients with acute bru- 
cellosis. The study was important to determine the relationship amoung serum PON1 activity, total thiols levels and some oxidative stress factors. They found that the patients have low TSH levels in low PON1 activities [32]. Interestingly, our results are not similar to given above literature. Even if the TSH levels fall, these results had no significant in our study, statistically (Table 1). Consequently, the TSH level in the case of AA may tend to be protected due to the antioxidant role of TSH in the oxidative stress defense mechanism.

GSH known as the master antioxidant is a vital part of antioxidant defense systems in metabolism. Glutathione plays the role of protection from oxidation the protein structures by the reduction of the disulfide bonds of cytoplasmic proteins to cysteines in the cell $[29,35]$. Moreover, this molecule is involving in many metabolic processes. Changes in the GSH levels may inform of crucial disorders in the metabolism. In our study, GSH levels were stable in between patients with $A A$ and the control group (Table 1). It was interesting and important result. Because this result show that AA causes less cellular damage than other many diseases.

Lipid peroxidation mainly caused by free radicals leads to oxidative destruction of polyunsaturated fatty acids formed by cellular membranes. On the other hand, the elimination of polyunsaturated fatty acids is reported to lead to the production of toxic and reactive aldehyde metabolites such as MDA [36]. MDA content is considered as crucial parameter reflecting the level of lipid peroxidation in oxidative stress studies. Increased MDA levels may be considered as an indicator of increased ROS. Studies have shown that MDA levels are elevated in patients with acute pancreatitis and AA. For instance, in a study on the plasma of the patients with AA, MDA levels were measured in the sample from 31 patients diagnosed as having AA. They saw that MDA levels were significantly higher than control groups. Thus, it has been understood that elevated MDA levels cause high free radical production which increases lipid peroxidation [37]. In another study carried out on patients with acute pancreatitis, plasma concentrations of malondialdehyde as a marker of lipid peroxidation were raised in acute pancreatitis patients compared with mild acute pancreatitis [38]. In our study, MDA levels in AA were similar to the previous reports. We found that the MDA levels of patients with acute perforated appendicitis (PeA) were higher than the control group (Table 1). These results indicate that elevated MDA levels cause the high free radical production. Thus, lipid peroxidation increase in the metabolic environment and this oxidative damage may be lead to many disorders as mentioned above.

Mean platelet volume (MPV) is a marker indicative platelet activation and size seen in the whole blood count. Conflicting results have been reported regarding the relationship between active inflammatory processes and MPV. Studies have shown that MPV is significantly lower in AA patients compared to control subjects [39]. In a study, it was shown that MDA levels increased in patients with $A A$. For instance, in a study on the plasma of the patients with AA, MDA levels were measured in the sample from 31 patients diagnosed as having $A A$. They saw that MDA levels were significantly higher than control groups [37]. As a result of our study, there is a strong negative correlation between MPV and MDA ( $r=-$ $0.654, p<0.01)$. It is thought that lipid peroxidation may increase with the decrease of MPV in patients with AA. (Figure 2).

In conclusion, concurrent assessment of some antioxidant enzymes with oxidative stress markers may be a key predictor of assessment of oxidative levels in AA, as well as a potential therapeutic target for pathological processes. Because, the changes of various enzyme activities and determining of some oxidative parameters may have been evaluated as a biomarker for many disorders. A significant differentiation of GST activity and MDA levels in patient groups leads to lipid oxidation which is caused by oxidative stress. From these results, increased GSH production elevated GST activity is an important defense mechanism against oxidation of some macromolecules. On the other hand, elevated MDA levels cause high free radical production which increases lipid peroxidation. In this aspect, the determination of both GST activity and MDA levels may be an important biomarker in the diagnosis and treatment of the disease. Another important result is decreased PON1 activity. If PON1 activity was decreased, it could be cause atherosclerotic lesions due to the LDL oxidation.

\section{Conflict of interest}

The authors declare that they have no conflict of interest.

\section{Acknowledgments}

The authors are grateful for the instrumental support that provided by the Research Foundation of Atatürk and Anadolu University. 


\section{References}

1. D.J. Shogilev, N. Duus, S.R. Odom, N.I. Shapiro, Diagnosing appendicitis: Evidence-based review of the diagnostic approach in 2014, West. J. Emerg. Med., 15 (2014) 859-871.

2. Y. Albayrak, A. Albayrak, M. Celik, I. Gelincik, I. Demiryilmaz, R. Yildirim, B. Ozogul, High mobility group box protein-1 (HMGB-1) as a new diagnostic marker in patients with acute appendicitis, Scand. J. Trauma. Resusc. Emerg. Med., 20 (2011) 19-27.

3. Y. Albayrak, A. Albayrak, F. Albayrak, R. Yildirim, B. Aylu, A. Uyanik, E. Kabalar, I.C. Güzel, Mean platelet volume: A new predictor in confirming acute appendicitis diagnosis, Clin. Appl. Thromb., 17 (2011) 362-366.

4. M.L. Nance, W.T. Adamson, H.L. Hedrick, Appendicitis in the young child: A continuing diagnostic challenge, Pediatr. Emerg. Care., 16 (2000) 160-162.

5. D.R. Flum, T. Koepsell, The clinical and economic correlates of misdiagnosed appendicitis: Nationwide analysis, Arch. Surg., 137 (2002) 799-804.

6. F.M. Yilmaz, G. Yilmaz, M.F. Erol, S. Köklü, D. Yücel, Nitric oxide, lipid peroxidation and total thiol levels in acute appendicitis, J. Clin. Lab. Anal., 24 (2010) 63-66.

7. H. SIES, Strategies of antioxidant defense, Eur. J. Biochem., 215 (1993) 213-219.

8. V. Stojiljković, A. Todorović, N. Radlović, S. Pejić, M. Mladenović, J. Kasapović, S.B. Pajović, Antioxidant enzymes, glutathione and lipid peroxidation in peripheral blood of children affected by coeliac disease, Ann. Clin. Biochem., 44 (2007) 537-543.

9. J.E. Klaunig, Y. Xu, J.S. Isenberg, S. Bachowski, K.L. Kolaja, J. Jiang, D.E. Stevenson, E.F. Walborg, The role of oxidative stress in chemical carcinogenesis, in: Environ. Health Perspect., 44 (1998) 239-267.

10. S.L. de Oliveira Machado, M.D. Bagatini, P. da Costa, J. Baldissarelli, K.P. Reichert, L.S. de Oliveira, J.G. Lemos, T. Duarte, M.R. Chitolina Schetinger,. V.M. Morsch, Evaluation of mediators of oxidative stress and inflammation in patients with acute appendicitis, Biomarkers., 21 (2016) 530-537.

11. M.S Özaslan, Y Demir, H.E Aslan, Ş Beydemir, Ö.I Küfrevioğlu, Evaluation of chalcones as inhibitors of glutathione S-transferase, J. Biochem. Mol. Toxicol., 32(5) (2018) e22047.

12. Y. Demir, Naphthoquinones, benzoquinones, and anthraquinones: Molecular docking, ADME and inhibition studies on human serum paraoxonase-1 associated with cardiovascular diseases, Drug Dev. Res., 81 (2020) 628-636.

13. H. Paşaoğlu, B. Sancak, N. Bukan, Lipid peroxidation and resistance to oxidation in patients with type 2 diabetes mellitus, Tohoku J. Exp. Med., 203 (2004) 211-218.

14. M. Kaya, M.E. Boleken, T. Kanmaz, O. Erel, S. Yucesan, Total antioxidant capacity in children with acute appendicitis, Eur. J. Pediatr. Surg., 16 (2006) 34-38

15. P.M. Reddy YN, Murthy S, Krishna DR, Role of free radicals and antioxidants in tuberculosis patients., Indian J Tuberc., 51 (2004) 213-218.

16. A.S. Veskoukis, M.G. Nikolaidis, A. Kyparos, D. Kokkinos, C. Nepka, S. Barbanis, D. Kouretas, Effects of xanthine oxidase inhibition on oxidative stress and swimming performance in rats, Appl. Physiol. Nutr. Metab., 33 (2008) 1140-1154.

17. M.S. Özaslan, Y. Demir, M. Aksoy, Ö.i. Küfrevioğlu, ş. Beydemir, Inhibition effects of pesticides on glutathione-S transferase enzyme activity of Van Lake fish liver, J. Biochem. Mol. Toxicol., 32 (2018) e22196.
18.

19. M. Gubandru, D. Margina, C. Tsitsimpikou, N. Goutzourelas, K. Tsarouhas, M. Ilie, A.M. Tsatsakis, D. Kouretas, Alzheimer's disease treated patients showed different patterns for oxidative stress and inflammation markers, Food Chem. Toxicol., 61 (2013) 209-214.

20. F. Renault, E. Chabrière, J.P. Andrieu, B. Dublet, P. Masson, D. Rochu, Tandem purification of two HDL-associated partner proteins in human plasma, paraoxonase (PON1) and phosphate binding protein (HPBP) using hydroxyapatite chromatography, J. Chromatogr. B Anal. Technol. Biomed. Life Sci., 836 (2006) 15-21.

21. M.L. Hu, Measurement of protein thiol groups and glutathione in plasma, Methods Enzymol., 233 (1994) 381385.

22. M.B. Grisham, Oxidants and free radicals in inflammatory bowel disease, Lancet., 344 (1994) 859-861.

23. T. Grune, M.M. Berger, Markers of oxidative stress in ICU clinical settings: Present and future, Curr. Opin. Clin. Nutr. Metab. Care., 10 (2007) 712-717.

24. R. Aktimur, A.K. Gokakin, K. Deveci, M. Atabey, O. Topcu, Oxidative stress markers in laparoscopic vs. open appendectomy for acute appendicitis: A double-blind randomized study, J. Minim. Access Surg., 12 (2016) 143-147.

25. J.N. Moloney, T.G. Cotter, ROS signalling in the biology of cancer, Semin. Cell Dev. Biol., 80 (2018) 50-64.

26. K. Yamamoto, P. Zhang, F. Miake, N. Kashige, Y. Aso, Y. Banno, H. Fujii, Cloning, expression and characterization of thetaclass glutathione S-transferase from the silkworm, Bombyx mori, Comp. Biochem. Physiol. - B Biochem. Mol. Biol., 141 (2005) 340-346.

27. J.L. Hearne, R.F. Colman, Contribution of the mu loop to the structure and function of rat glutathione transferase M1-1, Protein Sci., 15 (2006) 1277-1289.

28. J. Han, E.J. Won, D.S. Hwang, J.S. Rhee, I.C. Kim, J.S. Lee, Effect of copper exposure on GST activity and on the expression of four GSTs under oxidative stress condition in the monogonont rotifer, Brachionus koreanus, Comp. Biochem. Physiol. - C Toxicol. Pharmacol., 158 (2013) 91-100.

29. M. Sohail, A. Kaul, M. Raziuddin, T. Adak, Decreased glutathione-S-transferase activity: Diagnostic and protective role in vivax malaria, Clin. Biochem., 40 (2007) 377-382.

30. M. Işık, Ş. Beydemir, A. Yılmaz, M.E. Naldan, H.E. Aslan, i. Gülçin, Oxidative stress and mRNA expression of acetylcholinesterase in the leukocytes of ischemic patients, Biomed. Pharmacother., 87 (2017) 561-567.

31. Y. Demir, The behaviour of some antihypertension drugs on human serum paraoxonase-1: an important protector enzyme against atherosclerosis, J. Pharm. Pharmacol., 71 (2019) 1576-1583.

32. M. Işık, Ş. Beydemir, Y. Demir, M. Durgun, C. Türkeş, A. Nasır, A. Necip, M. Akkuş, Benzenesulfonamide derivatives containing imine and amine groups: Inhibition on human paraoxonase and molecular docking studies, Int. J. Biol. Macromol., 146 (2020) 1111-1123.

33. R. Esen, M. Aslan, M.E. Kucukoglu, A. Cıkman, U. Yakan, M. Sunnetcioglu, S. Selek, Serum paraoxonase activity, total thiols levels, and oxidative status in patients with acute brucellosis, Wien. Klin. Wochenschr., 127 (2015) 427-433.

34. E.G. Dumlu, M. Tokaç, B. Bozkurt, M.B. Yildirim, M. Ergin, A. Yalçin, M. Kiliç, Correlation between the serum and tissue levels of oxidative stress markers and the extent of inflammation in acute appendicitis, Clinics., 69 (2014) 677- 
682.

35. H. Koksal, Total oxidant status, total antioxidant status, and paraoxonase activity in acute appendicitis, Turkish J. Trauma Emerg. Surg., 21 (2015) 139-42.

36. M. Işık, Y. Demir, M. Kırıcı, R. Demir, F. Şimşek, Ş. Beydemir, Changes in the anti-oxidant system in adult epilepsy patients receiving anti-epileptic drugs, Arch. Physiol. Biochem., 121 (2015) 97-102.

37. E.M.M. Ali, H.H. Shehata, R. Ali-Labib, L.M. Esmail Zahra, Oxidant and antioxidant of arylesterase and paraoxonase as biomarkers in patients with hepatitis $\mathrm{C}$ virus, Clin. Biochem., 42 (2009) 1394-1400.
38. U. Koltuksuz, E. Uz, S. Özen, M. Aydinç, A. Karaman, Ö. Akyol, Plasma superoxide dismutase activity and malondialdehyde level correlate with the extent of acute appendicitis, Pediatr. Surg. Int., 16 (2000) 559-561.

39. M. Abu-Hilal, M.J.W. McPhail, L. Marchand, C.D. Johnson, Malondialdehyde and superoxide dismutase as potential markers of severity in acute pancreatitis, J. Pancreas., 7 (2006) 185-192.

40. C. Sen Tanrikulu, Y. Tanrikulu, M. Zafer Sabuncuoglu, M. Akif Karamercan, N. Akkapulu, F. Coskun, Mean platelet volume and red cell distribution width as a diagnostic marker in acute appendicitis, Iran. Red Crescent Med. J., 16 (2014) 10211. 